\title{
Digitalization of the Residential Mortgage Market in Crisis Conditions: Main Factors and Drivers of Development
}

\author{
Larisa Yuzvovich ${ }^{1, *}$, Maria Sharafieva ${ }^{1}$, Natalia Mokeeva ${ }^{1}$, and Gulmira Nasyrova ${ }^{2}$ \\ ${ }^{1}$ Ural State University of Economics, 620144 Ekaterinburg, Russia \\ ${ }^{2}$ L.N. Gumilyov Eurasian National University, 010008 Astana, Kazakhstan
}

\begin{abstract}
The industrialization of the residential mortgage market during the pandemic has undergone significant changes, like all sectors of the economy, including the banking system. During the transformation, a positive dynamics has been noted in the volume of loans, which contradicts the usual scenarios for the behavior of the mortgage market in the period of the unstable macroeconomic situation in recent years. The crises of 2008 and 2014 showed the vulnerability of the banking system and the market for residential mortgage market, the lack of timely measures to prevent drastic consequences for the banks and the state. At the moment, it is important to understand what drivers triggered the growth in the volume of residential mortgage. The research analyzed the reasons that had a key impact on the mortgage market and the banking sector during the covid-19 pandemic. As a result of the study, the main factors that help to draw up directions and digital algorithms for further development have been highlighted and classified.
\end{abstract}

\section{Introduction}

In recent years, the macroeconomic situation has exposed a whole range of problems in the dynamically developing system of residential mortgage in Russia - a fall in the value of real estate collateral, a sharp increase in overdue debt on issued residential mortgage, low efficiency of the Agency for Residential Mortgage [11]. 2019 is a plateau year for the banking sector in the direction of residential mortgage, with stable and durable development vectors for 2020. By the beginning of 2019, the main drivers of mortgages, such as low interest rates, relatively stable property prices, low down payment, the need for refinancing, had exhausted themselves. In connection with the upcoming increase in interest rates, some borrowers hastened to close mortgage transactions by the end of 2018 , which was a record of 3 trillion RUB in loans, thereby realizing part of the demand from 2019. The regulator has also increased the risk ratio for mortgages with an initial payment of less than $20 \%$, a number of key banks left the loans with the possibility of making a contribution below this mark, which provoked a decrease in the demand of a significant

\footnotetext{
* Corresponding author: yuzvovich@bk.ru
} 
part of the borrowers. The rise in housing prices contributed to an increase in the average loan amount to 2.24 million RUB, which is by 240 thousand RUB more than that of the previous year (Table 1). In addition, the dynamics of the increase in real estate prices was influenced by the transition of developers to the system of bank funding, work through escrow accounts, while the equity holders began to feel more protected by the state. In May 2019 , the rate reached $10.5 \%$, a sharp increase provoked a decrease in demand, and as a result, we see a non-critical drop in the volume of issues compared to the previous year by $5 \%$.

The beginning of 2020 was marked by several important events at once, which test the immunity of the Russian banking system to crisis situations.

The topic of the crisis is one of the most popular today. A crisis, translated from Greek, means a turning point, the outcome of which is sharp with an abrupt change and difficult transitional state. It can also mean "way out, solution to the conflict (for example, military one)." In the 19th century, this concept passed into economics. The "classical" definition of the crisis was replaced by the more ambiguous concept of "economic crisis". Borisov A. B. defines the economic crisis as "a sharp deterioration in the economic state of the country, which manifests itself in a significant decline in production, disruption of the existing industrial relations, bankruptcy of enterprises, an increase in unemployment and, as a result, in a decrease in the standard of living and well-being of the population. The authors of the most popular textbook of the 70s-80s. - "Economics" - Steinlin Fischer, Rudiger Dornbusch and Richard Schmalenzi [6], also proceeding from the fact that the crisis is an integral part of the economic cycle, give the following definition: "when an imbalance of a different nature occurs in the economy, monetary and fiscal policy changes, new products or new production methods appear, people's consumer preferences or job preferences change, the prices of oil and other raw materials change, etc., aggregate demand curves shift, and output and prices change in parallel with these shifts. The aggregate demand curve may shift at any time due to changes in monetary and fiscal policy or because the private sector's demand for output in the economy has changed. Changes in oil prices and wages are also manifested in the form of shifts in the aggregate supply curve" [9]. In the current crisis scenario, the key was the fall in oil prices, as a result of a sharp decline in demand for "black gold" from such large exporters of the world market [2] as China, the USA and the EU countries. In April 2020, a non-working day regime was introduced, as part of countering the spread of the coronavirus infection. For the first time in recent history, a pandemic has led to a deliberate (by the decision of almost all governments) suspension of the activities of most sectors of the economy. As a result, the activities have been carried out only by strategically important objects (defense industry, fuel and energy complex, telecommunications, etc.) and vital (agro-industrial complex, pharmaceuticals, trade in food and essential goods). Such spheres as hotel, tourism, concert business, beauty industry, catering, transport services, air transportation, dental services and companies providing additional education in various areas have suffered huge losses. As the Minister of Economic Development Maxim Reshetnikov has reported, there are 42 affected types of activity, employing more than 6 million people. The pandemic affected up to $67 \%$ of small, medium and large enterprises, as well as individual entrepreneurs in Russia, follows from the report of the business ombudsman Boris Titov. The current situation affected the employment of the population - unemployment increased, as a result, at the income level some of the citizens employed in the most affected types of activity lost their income.

In May 2020, the unemployment rate reached its highest value in the last eight years and stood at $6.1 \%$. By the end of May, $45 \%$ of companies across the country had announced the redundancies. In turn, this affected the consumer demand, citizens began to buy only the most necessary things, the cost of the grocery basket decreased, due to the choice of 
cheaper products, large purchases acquired a delayed effect, and therefore the demand for credit products decreased.

\section{Methods and Types of the Earth's Remote Sensing}

The dramatic changes as a result of the covid-19 pandemic in all sectors of the economy directly affected the banking services market and the residential mortgage sector. First of all, all banks have adjusted the risk rule. The borrowers in the industries such as tourism, hotel business, small business owners and transportation companies have been placed in the risk group of clients in most banks and have received an unspoken ban on lending.

The article reveals the shortcomings of the methodology for determining the housing affordability ratio, contained in the legislation, due to the fact that it does not take into account the current expenses of the households. It has been proposed to adjust this indicator by the value of the subsistence minimum for each of the family members. The calculation has been performed using a modified calculation model. The application in practice of a simpler and more objective indicator of housing affordability for the population, which is the ratio of the population's income to the cost per square meter of residential real estate [1].

Loan officers have also noted declining in approval rates for high-risk products such as credit cards and unsecured cash loans and an increase in rejections. This suggests that the banks have revised the scoring system, using the so-called "spin" scoring method. Large purchases requiring credit backing became suspensive. Analysts of such large banks as UralSib and Absolut note a decrease in quality demand and an increase in demand, which does not correspond to the Bank's policy. Also, "Absolute" Bank speaks about an increase in the number of requests for restructuring by $2-3 \%$ (according to expectations, an increase of up to $10 \%$ is possible). A number of banks announced the abolition of preferences in the form of discounts for internal categories of clients - salary, regular customers, holders of privileged cards. We observed similar correlations between banks' risk and monetary policies in the same crisis periods of 2008 and 2014. In order to analyze in detail what is currently happening with the residential mortgage market, the authors of the study propose to analyze the macroeconomic indicators in RMM sector for 8 months of 2020 and compare with the indicators for the same period of the previous 2019 and 2018. (Table 1). Over the past 8 months of 2020, the volume of loans issued amounted to 2,147,126 million rubles, which is $16 \%$ more than the record year of 2018 . At the same time, the number of loans in pieces is only $5 \%$ less than in the same period in 2018 . Here it is worth paying attention to the average mortgage amount, which has grown by almost 500,000 rubles and reached 2,406,377 million rubles. (Table 1).

Table 1. Analysis of macroeconomic indicators of the residential mortgage market [8]

\begin{tabular}{|l|l|l|l|}
\hline Key performance indicator & 2020 & 2019 & 2018 \\
\hline Number of credits (pcs.) & 892,265 & 838,449 & 939,610 \\
\hline Volume of loans (million rubles) & $2,147,126$ & $1,838,265$ & $1,849,344$ \\
\hline Average mortgage amount (million rubles) & $2,406,377$ & $2,192,458$ & $1,968,203$ \\
\hline Weighted average rate (\%) & 8.2 & 10.21 & 9.66 \\
\hline Weighted average term (months) & 219 & 212 & 192 \\
\hline
\end{tabular}

First of all, it should be noted that a period of general economic decline with colossal financial losses and a decrease in volumes in all areas of activity, including the general market of banking services, we can see an increase in the volume of loans in relation to previous years in mortgage lending. If we turn to the history of the crisis periods of 2008 and 2014, we will see that in the usual scenario, the crisis year gave a sharp decline in the 
volume of loans and in the demand for mortgage lending. So, following the results of the 2014 crisis, we saw a drawdown of $-34 \%$. We are also seeing a record decline in the level of interest rates to a historic low of 8.2\%, while in the last two crises of 2008 and 2014, we saw only a sharp increase. For example, in December 2014 the minimum rate at Sberbank was $14.5 \%$, and the maximum rate was $16 \%$ [7].

Despite the active growth in the volume of loans issued and the stability of indicators, we observe a picture of an increase in the growth of overdue debt, starting from April (Graph 1). It was during this period that the peak of the non-working days introduced as part of countering the spread of the pandemic fell. Some of the quarantined employees were dismissed from the state by agreement of the parties without any payments, a number of positions were abolished and responsibilities were distributed among the remaining employees. In order to stay working, the employees agreed to take vacations without paying until the end of the unscheduled vacation. Particularly difficult in terms of wages was for those who have a piece-rate form of payment or dependent on sales figures. Government support for small businesses began to operate in full force in May, when most employers have already made personnel changes. Restructuring, as a product of supporting borrowers in difficult financial situations, does not play a big role in this case, since in fact, it makes it possible only not to pay for several months, while there is a redistribution of debt for the remaining months and, as a result, an increase in either the amount of the monthly installment or the term. A small part of citizens fell under the credit holidays introduced by decree of the President of the Russian Federation due to the fact that an official reduction from the employer or a family member who fell ill with covid-19 was required. As a result, we see a peak in overdue debt in September 2020, an increase compared to the same period in 2019 by RUB 5,314 million.

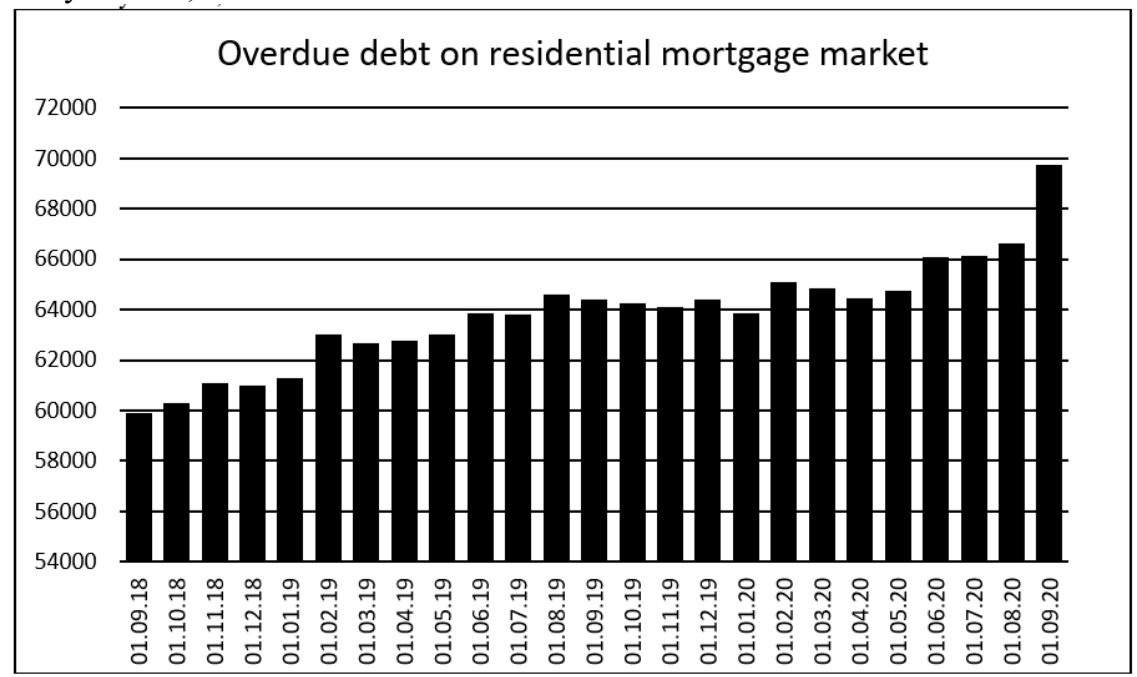

Fig. 1. Volumes of overdue debt on residential mortgage market [10]

As one of the main consequences of the "crown of the crisis" tightening of the credit risk policy of unsecured lending, consumer lending and all derivative unsecured credit products are the first to suffer. As a result, the banking sector is losing a significant chunk of profits and assets, as retail lending has remained a highly marginal product in recent years. If a number of banks do not change their risky approach to unsecured lending, then in a year we will see a picture of a noticeable deterioration in the quality of the loan portfolio. In this case, secured residential mortgage market acts as a safety cushion for banks. Residential mortgage market is the best asset of Russian banks in terms of credit 
quality in recent years. Therefore, it is very important to understand which drivers help residential mortgage market to form this safety cushion for banks and not to reduce the volume of loans, which determines the relevance of this study. We propose to consider in more detail the changes in the residential mortgage market that have occurred as a result of the impact of the covid-19 pandemic, which will help to analyze and compose an algorithm of actions in specific directions for participants in RMM in a difficult macroeconomic situation. In the course of their work, the authors use such scientific methods as statistical data analysis, comparison with similar crisis periods in 2008 and 2014, classification of factors affecting RMM during a pandemic, generalization. The subject of this research is the economic relations arising in the field of residential mortgage market and proceeding during the period of the general macroeconomic recession against the background of the crisis.

\section{Results and Discussion}

The European scientists assess the impact of changes in the growth rate of gross domestic product (GDP) and inflation on the volume of residential loans. The analysis is carried out using vector autoregressive (VAR) and generalized VAR-approaches for the entire sample and for each country under consideration [12].

The banking sector of Russia has a special specifics, it approached the crisis of 2020 more prepared than in the similar crisis macroeconomic periods of 2008 and 2014. The impact on the consumer behavior of the country's population regarding the mortgage products and lending programs offered by banks is considered from the standpoint of the influence and systematization of demand factors [5]. The authors of the study, in turn, identified and classified the following number of factors that directly influenced the stability of the situation on RMM in 2020.

State regulation

1. Mass cleanup of credit institutions and, as a result, weaker competitors leave the market. As of January 1, 2009, the number of banking institutions was 1108, while as of January 1, 2020, this figure was more than half of 442 operating banks. The process of cleanup and rehabilitating the banking sector was launched at full speed after the last crisis of 2014, when the Central Bank and the DIA faced the situation of the need to organize massive payments to several banks at once, which fell under license revocation due to dirty assets, inaccurate reporting, insufficient capital, inability to meet the requirements for credit obligations, risky credit policy and violation of the requirements prescribed by 115 Ф3. According to official data, as of 01.04.2018, the number of credit institutions issuing mortgage loans was 403; as a result of the cleanup, as of 01.07.2020, the number of credit institutions decreased by $25 \%$ and is 302 organizations. This suggests that at the moment only those participants operate on RMM, whose business model meets the current requirements of the Central Bank and meets the standards, first of all, of the quality of the loan portfolio and liquid collateralized lending. This primarily contributes to the formation of a reliable and sustainable safety cushion in the event of a sharp drop in indicators for unsecured credit products.

2. An increase in the number of state-owned banks, which have already formed the foundation of the banking system and set the basis for the product line and interest rates.

3. State support program. This is a whole set of tools and opportunities for the country's population, banks, developers and builders. At the moment, the following programs have been developed and implemented:

- Subsidizing the mortgage rate from the state. In April 2020, the government announced the launch of a subsidized mortgage program with state support at 6.5 percent by decree of the President of the Russian Federation. The goal of this 
program is, first of all, to support the construction industry in Russia and additionally attract about 900 billion rubles to it at the time of a drop in demand due to quarantine measures and a drop in household income. The program applies only to the purchase of real estate in the primary market from legal entities, is valid until November 01,2020 , for the entire period the borrower is fixed at a rate of $6.5 \%$, the percentage over the bank is compensated by the state. As of October 8, 2020, banks under this program have approved about 500 thousand applications, concluded 224.4 thousand loan agreements for 630.8 billion rubles. According to analysts from Dom RF, $90 \%$ of all transactions on the purchase of real estate in the primary market from legal entities fall on the state support program. This measure has been efficiently adopted, the Ministry of Finance is currently discussing the extension and increase of the limits. The program makes mortgages available to most of the population, the construction industry develops and continues to function without decreasing volumes, the bank mortgage portfolio is increasing in volume, thereby increasing the collateral and liquidity cushion.

- Mortgage under maternity capital - the ability to use maternity capital funds for registration, repayment of a mortgage loan and, most importantly, use it in the initial payment, which has become possible only in recent years.

- Social mortgage - also includes a set of programs such as regional programs to support mortgage borrowers, for example, the mortgage operating in the KhantyMansi Autonomous Okrug, Surgut, for the employees of Surgutneftegas JSC, gives the right to compensation rates from the region. Mortgage loan for the Far East is at 2\%. Programs "Young Family", "Housing for a Russian Family"

- Military mortgage. The state pays for the mortgage under this program for the military people. Also, a serviceman has a special account, money from the state is regularly credited to it with the aim of selling it for the purchase of housing. These funds can be spent on the first installment.

- 6 percent family mortgage. As part of the increase in the country's demography, the availability of real estate acquisition and maintenance of the primary market, in 2017, a mortgage was launched for families who gave birth to their second and third child after January 1, 2018, which entitles them to a $6 \%$ rate. At the same time, a number of banks provide interest less than 6 , for example, Promsvyazbank $4.5 \%$, which again increases the availability of mortgage loans for borrowers.

Social and educational factor

Increasing financial literacy of the population, a factor that played a key role during the onset of the covid-19 pandemic and the subsequent economic crisis. Having analyzed the behavior of the population during the crisis periods of 2008 and 2014, the authors of the study distinguish two behavioral paths:

1. Impulsive withdrawal of free funds from a bank with a high level of reliability, but a low interest on the deposit and subsequent placement at a higher interest rate in a credit institution with a low level of reliability.

2. Irrevocable cash withdrawal, conversion into foreign currency and home storage without opening bank accounts.

Both paths are united by the psychological fear of losing money, the ability to correctly perceive and assess what is happening is lost, which further leads to mass infection and the beginning of panic. As a result, rampant withdrawals, queues and mass congestion in bank offices, the collapse of credit institutions with a minimum level of reserves and dirty assets, which undermined the banking system as a whole. The Ministry of Finance has introduced a strategy to improve the financial literacy of the population for $2017-2023$. A wide range of activities has been developed to implement this program - seminars, conferences, olympiads for schoolchildren and students of universities and educational institutions, full- 
time and distance courses for the middle age category on the basis of employment centers, the introduction of sites, Internet pages and applications aimed at acquiring knowledge in the field of finance and monetary circulation [9]. The results of a study by "NAFI" analytical center of the level of financial literacy for 2019 have shown a positive trend of + $2 \%, 71$ regions represented a positive trend in the financial literacy index. The crises of past years 1998, 2008, 2014 literally forced citizens to come to an understanding of the need to have knowledge in the field of finance. It is also worth paying attention to weekly partnership days from bank employees on the territory of salary project enterprises, organizing round tables from mortgage brokers, real estate agencies, introducing open days from developers, organizing free forums in full-time and remote format from the largest banks. All of the above activities in combination contributed to the accumulation of knowledge in the field of finance among the population, which played a cushioning effect during the onset of the 2020 crisis, reduced panic and the subsequent collective chain reaction.

Progress of bank digitalization

1) Information availability. For the majority of the population, who find themselves on non-working days, which lead to a significant decrease in the level of income, the main criterion in working with financial institutions was the availability of information, the ability to quickly communicate with a bank or an employee to receive instructions, a variety of communication channels and the willingness of banks to explain the situation and help the client. The process of switching to a remote service format, the so-called process of digitalization of the banking system, received a very powerful impetus due to the pandemic. First of all, the well-functioning work of banking services is important for the client:

- call centers with separate lines for restructuring loans and cases related to receiving benefits and subsidies, as affected by the pandemic

- working sites with a full set of tools, as well as the availability of information on changes in the operating modes of departments, additional phones in different directions

- personal offices and applications that allow you to quickly access your accounts without visiting the bank's office - transfer, convert, open a deposit, apply for credit products, including mortgage, as well as get the necessary information, order the certificates.

- availability of quick chats to communicate with employees on the site or in the application

- sendings and notifications, allowing customers to see the involvement of banks and willingness to help

- availability of pages on social networks with publications of relevant information online

- possibility of digital cards registration

Digitalization is, first of all, the digitization of processes in the bank, which allows you to derive a clear algorithm of work, with a reduction in the number of links in the chain, to increase the productivity of the entire system. In a pandemic, banks have concentrated their efforts on creating conditions for the continued functioning of business for clients, both individuals and legal entities, in a remote format. During the pandemic, key banks introduced home delivery of cards, which was positively evaluated by the customers. Also, systemically important banks are involved in issuing loans at $0 \%$ to pay salaries to employees of enterprises, affected industries and provide credit holidays for business. For convenience and to avoid queues during a pandemic, the loan restructuring procedure has also become available online. The most complex transactions involving registration authorities are mortgage loans, a full cycle of online transactions is possible in several banks. During the pandemic, the activity of digital channels among the bank's clients has 
significantly increased. The number of sessions at VTB-Online in March increased by one third compared to the previous month. Now the VTB-Online application is used by more than $60 \%$ of the bank's clients, the share of remote settlement transactions is approaching $100 \%$, more than $99 \%$ of brokerage business transactions are carried out in online channels. Even before the introduction of self-isolation, up to $60 \%$ of savings products were opened online; in April, the share of registration of savings products through remote channels increased even more. At the same time, in April compared to March, we note an increase in the share of online applications for mortgages by $9 \%$, for cash loans - by 1.5 times, for car loans - by $60 \%$ [4].

According to the Bank of Russia, in 2018 the share of the adult population that can instantly transfer funds using a mobile phone increased from 36 to $55 \%$, and the share of banks that open a bank account without a client visiting a bank office increased from 14 to $22 \%$. Therefore, banks are optimizing the network of departments and personnel in order to reduce costs. Since 2016 , the number of bank subdivisions has decreased by $15 \%$, banks were most actively closing cash desks outside the cash register $(-87 \%$, their number decreased from 6.7 thousand to 0.9 thousand) and branches (-64\%, a decrease from 1.7 thousand to 0.6 thousand). Also, in order to reduce the costs of maintaining the divisions, banks are "lightening" the format of offices, reformatting some branches and additional offices into credit and cash offices: the number of cash register offices increased in 2019 by $15 \%$ from 1.9 thousand to 2.2 thousand. The collected data shows a significant gap between large and small banks in the level of digitalization of operations: for example, in 2019, the average share of online sales of basic banking products for the top 100 banks by assets was $22 \%$, and for banks outside the top 100 - just 9\%. In 2020, large banks with an Expert RA credit rating are going to significantly increase the share of online sales (by an average of 6 pp to $28 \%$ ), which will noticeably widen the gap in the level of digitalization of sales of large and small banks. [8]

Product adjustment

1) Secured lending program Allows you to issue a mortgage loan for the purchase of real estate, which is already pledged by another creditor bank. The introduction of this instrument into the product line in a number of banks gives an advantage over many market participants. The program is relevant for families with the intention to expand, but at the same time there is no free money to pay off the existing mortgage loan in order to withdraw it from the mortgage, sell an apartment on the secondary market and buy with a larger area. At the moment, only key players are working on this program, for example, Sberbank, VTB, Raiffeisenbank, etc.

2) Historical minimum in mortgage interest rates. According to the Central Bank, as of August 1, 2020, the weighted average rate on housing loans set a new historical minimum $-7.28 \%$. According to the authors of the study, the low interest rate is a key driver for the growth of sales of mortgage loans and residential real estate, which primarily ensures the availability of mortgages. We can clearly see confirmation of this fact in the results of mortgage products issued in August and September 2020. (Chart 2) Issuance of mortgages increased as compared to Q3 2019 by 53\% in quantitative terms and by $75 \%$ in monetary terms. In September 2020, 180-185 thousand mortgage loans were issued $(+71 \%$ compared to September 2019). The amount of loans issued reached 470 billion rubles, which is twice as much as a year earlier. Also, a key role in reducing rates was played by a preferential mortgage program for new buildings at a rate not higher than $6.5 \%$, implemented on behalf of the President of the Russian Federation, which turned out to be an effective anti-crisis measure to support the mortgage market and the housing construction industry. [4] 


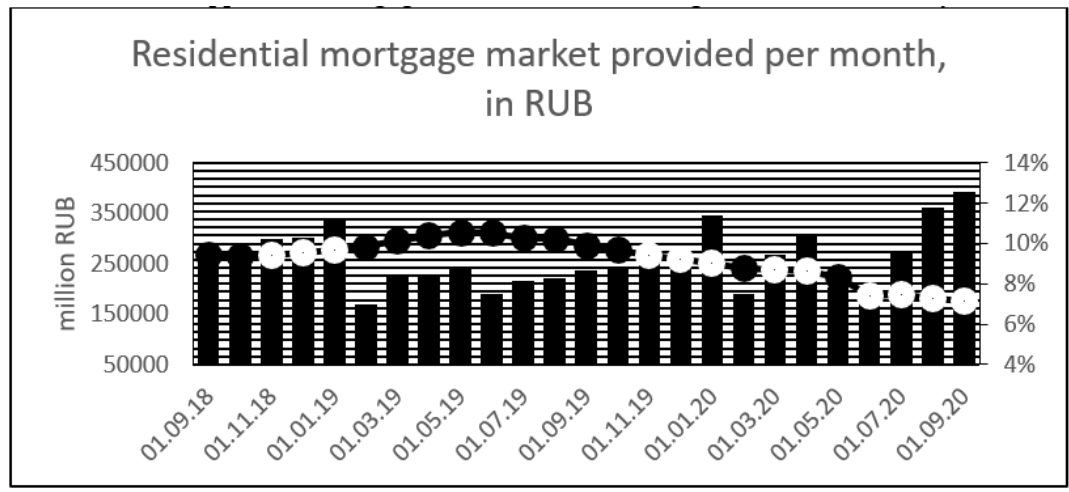

Fig. 2. Number of mortgage products

3) Increased demand for suburban real estate. Due to the covid-19 pandemic, the suburban real estate market has revived after a long downtime. According to Avito Real Estate analysts, at the end of March, this segment felt the consequences of the current economic situation, however, by the beginning of July it not only came out of the crisis but also exceeded last year's indicators: the demand for purchase increased by $77.7 \%$ in comparison with the results for the same period of 2019 (Diagram 3)

For the banks whose product line included this program or those who could quickly implement it, of course, this gives a separate advantage and additional growth in the volume of loans. First of all, the pandemic has shown the vulnerability of modern cities to containment of serious diseases and activated the de-urbanization trend, in which people tend to move outside the city and equip their living and working space there. Health turned out to be in the first place among the population, therefore, for social distancing, they decided to change a small city apartment for a spacious plot. In many ways, this became possible thanks to the remote work format. According to a survey by the Center for Strategic Development, $68 \%$ of companies plan to maintain remote mode for some employees after the pandemic. This fact gives reason to believe that the demand for suburban real estate will only grow. [4]

\section{Dynamics of demand in the suburban real estate market in the purchase category, March-July 2019 - March-July 2020}

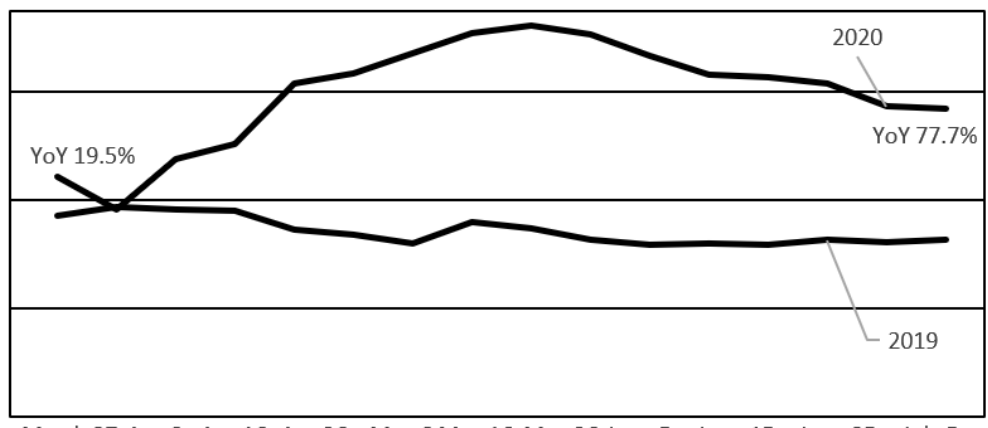

March 27 Apr 6 Apr 16 Apr 26 May 6 May 16 May 26 June 5 June 15 June 25 July 5

Fig. 3. Dynamics of demand in the suburban real estate market in the purchase category

Active tuning of the affiliate channel. Rapid restructuring of the developers, builders and large real estate agencies. According to the authors of the study, this factor is also one of the key ones, in view of the fact that the residential mortgage market is a well- 
coordinated work of a number of links, real estate agencies and developers are an integral part of this chain. The covid-19 pandemic has made adjustments to the work of real estate agencies, as a result of the restructuring, developers have the option of online demonstration of apartments, without the departure of the client and the employee. A full consultation cycle with most developers, for example, RSG, Brusnika, LSR, became possible without visiting the office. Signing of the contracts for the provision of agency services for the purchase of apartments and payment of the down payments also became available remotely, in order to comply with quarantine measures, but with the preservation of loyalty to the customers. A number of the developers have introduced the preferential programs for the categories of citizens most involved in eliminating the consequences of the covid-19 pandemic - the RSG developer has introduced a 3\% discount for medical workers on the purchase of an apartment. Joint shares of the bank and the developer, for example, PIK Group of Companies, when applying for a mortgage loan through Absolut Bank, the borrower does not pay interest for 1 year.

Fluctuations in the value of mortgaged real estate collateral for mortgage loans are critical to maintaining the reliability of marketable mortgage securities. Despite the high quality of the creditworthiness of Russian mortgage borrowers, ignoring trends in the real estate market may lead to a decrease in confidence in the capital market and other crisis phenomena. In the current conditions of limited sources of funding for commercial banks, securitization is becoming increasingly important for the development of mortgage lending and other areas [3].

\section{Conclusions}

Therefore, we can conclude that the methods of operational transformation to adjust to the working conditions during the pandemic were effective and provoked a growth spurt in many processes in the housing mortgage sector and the banking system as a whole. The managers of many banks said that the plan for the transition to online platforms and the transfer of $100 \%$ of operations to remote mode was scheduled step by step for the next 3-5 years, while in a short period of time from February to May it was possible to rebuild the work of all links and reduce the transition mode to 6 months - 1 year. Clients appreciated the convenience of working in this mode, first of all, it saves time on the trip to the bank and waiting in line. That is why banks with a high level of digitalization turned out to be far ahead and out of competition from the main mass with the lack of the ability to quickly restructure. The remote format of the bank's employees showed that with a "quality" employee, the efficiency of the working day increases 2 or more times. The organization of the workplace within the walls of the house ensured the availability of the employee for the client on a $24 \times 7$ basis as well. All of the above factors in aggregate have provided a powerful support for mortgage lending, forming a reliable safety cushion for the banking system. It is worth paying attention to government regulation and timely provision of assistance to the construction industry, the banking sector and the population, introducing a government rate subsidy program in April, as part of support measures during the covid-19 pandemic. Banks that have a set of all instruments of state assistance in obtaining mortgage loans in their product line, show higher results in terms of the volume of loans and the growth of the client base. In January-August 2020, under mortgage programs with state participation, 217.4 thousand loans have been issued in the amount of 590.2 billion rubles. This represents $24 \%$ of all mortgage issues since the beginning of the year and $80 \%$ of mortgage issues in the primary market. We also see confirmation of this fact, primarily in growth figures, the mortgage portfolio (including securitization) as of September 1, 2020, for the first time exceeded 9 trillion rubles $-8-8.5 \%$ of GDP. The active resumption of demand in the suburban real estate market speaks of a change in the main criteria for 
buying real estate, to which RMM needs to be quickly adjusted. The pandemic has shaped the changing needs. A significant part of the borrowers began to choose the apartments with a larger area, referring to the fact that the remote format of work may continue even after the end of the pandemic. Personal space and isolation have come to the fore, as evidenced by the demand figures for suburban real estate $+77.7 \%$ by 2019 . Partnership agreements between the developers and banks allow the exchange of customer bases, increase loyalty and are a powerful tool for mutually beneficial support during a pandemic. Organization of round tables jointly with real estate agencies, banking days on the territory of payroll client companies, joint open days with developers increase the level of financial literacy of the population, increase the percentage of trust in the bank, and strengthen the partnerships. Mortgages remain the highest quality product for lending to the individuals. Against the backdrop of a record mortgage issue in the summer months, portfolio growth on an annualized basis accelerated to $14.5 \%$ in August. The share of overdue debts over 90 days remains at the level of about $1.5 \%$, while on other loans of the population it exceeded $8 \%$.

\section{References}

1. A. L. Belousov, Actual problems of economics and law, 13(1), 935 (2019)

2. I.A. Dolmatovich, N.V. Kesenkova, Finance and credit, 24 (2018)

3. S.A. Potomonova, Finance and credit, 26 (2020)

4. Development of the market for residential mortgage market and the activities of the AHML, dom.rf, https://xn--d1aqf.xn--p1ai/

5. E.V. Sinyakova, Finance and credit, 26 (2020)

6. S. Fischer, R. Dornbush, R. Schmalenzie, Economic portal, https://institutiones.com/

7. Analytical data on mortgage lending for 2014-2018, raexpert.ru, https://raexpert.ru/

8. Information about the residential mortgage market in Russia 2013-2020, https://cbr.ru/

9. Official website of the Ministry of Finance of the Russian Federation, Information about the level of financial literacy, https://minfin.gov.ru/ru/

10. Mortgage loan disbursements statistics 2009-2019, http://rusipoteka.ru/

11. Ekaterina Zinovieva, Margarita Kuznetsova, Lilia Votchel, 6th International Academic Conference on Strategica - Challenging the Status Quo in Management and Economics Location: Bucharest, OCT 11-12 (2018)

12. Umberto Filotto, Claudio Giannotti, Gianluca Mattarocci, Journal of property investment \& finance, 36(6), 552 (2018) 